\title{
Alloxan-Induced Alteration of Insulin Release, Rubidium Efflux and Glucose Metabolism in Rat Islets Stimulated by Various Secretagogues
}

\author{
J. C. Henquin, P. Malvaux, and A. E. Lambert \\ Unité de Diabète et Croissance, University of Louvain School of Medicine, UCL 54.74, Brussels, Belgium
}

\begin{abstract}
Summary. Insulin release and ${ }^{86} \mathrm{Rb}$ efflux were studied in perifused rat islets exposed in vitro to alloxan $(2 \mathrm{mmol} / \mathrm{l})$ for $5 \mathrm{~min}$. At a low glucose concentration, alloxan transiently increased ${ }^{86} \mathrm{Rb}$ efflux. Alloxan immediately and completely abolished the secretory response to glucose $(15 \mathrm{mmol} / \mathrm{l})$ and markedly delayed the reduction in ${ }^{86} \mathrm{Rb}$ efflux normally produced by the sugar. $3-0$-methylglucose $(20 \mathrm{mmol} /$ 1) provided complete protection against the alteration of ${ }^{86} \mathrm{Rb}$ efflux and partial protection against the inhibition of insulin release. Immediately after alloxan treatment, glyceraldehyde, $\alpha$-ketoisocaproic acid and tolbutamide still induced a rapid release of insulin, but the late phase normally stimulated by glyceraldehyde and $\alpha$-ketoisocaproic acid was inhibited. If islets were exposed to glyceraldehyde or tolbutamide $15 \mathrm{~min}$ after alloxan treatment, the rapid insulin release was also markedly impaired. Alloxan failed, however, to affect the ability of these three stimuli to reduce ${ }^{86} \mathrm{Rb}$ efflux from islet cells. Glucose oxidation and utilization were decreased in alloxantreated islets and 3-O-methylglucose protected against this effect. The results show that the glucose recognition system in B-cells is the most rapidly and severely affected by alloxan. The drug also alters the response to other secretagogues, the insulin releasing properties of which can be impaired without alteration of their ability to reduce ${ }^{86} \mathrm{Rb}$ efflux.
\end{abstract}

Key words: Isolated rat islets, alloxan, perifusion, insulin release, rubidium efflux, glucose metabolism, glucose, glyceraldehyde, $\alpha$-ketoisocaproic acid, tolbutamide.

Alloxan has been widely used to induce experimental diabetes [1], but the exact mechanisms by which the drug produces a relatively selective destruction of pancreatic B-cells remain elusive. Elucidation of the molecular mechanisms of its action would certainly be of more than pharmacological interest. Indeed, observations that glucose can protect B-cells against alloxan toxicity $[2,3]$ make the drug a potential probe of the physiological stimulus-secretion coupling.

Present experimental evidence, recently discussed in detail [4], suggests that the B-cell membrane may be an important site of the action of alloxan. In mouse islets alloxan produces depolarization of Bcells [5] and inhibition of the univalent cation pump [6]. In rat islets it produces a loss of membraneassociated particles [7]. In toadfish islets [8], but not in rat islets [9], it increases the membrane permeability to mannitol, which is normally restricted to the extracellular space.

Recent studies have shown that glucose rapidly and markedly decreases potassium efflux from rat islet cells [10]. This supports the suggestion [11] that the depolarization of B-cells produced by the sugar [12-13] might be due to a reduction in K-permeability. The importance of these changes in K-permeability is underlined by the evidence that pharmacological agents which potentiate the effect of glucose on K-permeability also potentiate its insulin releasing effect, whereas those which augment K-permeability antagonize the insulinotropic action of the sugar [14-16].

In the present experiments, perifused isolated rat islets were exposed to alloxan for $5 \mathrm{~min}$ [17] in order to (a) compare the inhibitory effects of the drug on insulin release stimulated by various agents, $(b)$ determine whether any alteration of the effect of these secretagogues is related to an impairment of their property to change the K-permeability of islet cells (evaluated by changes in ${ }^{86} \mathrm{Rb}$ efflux), and (c) investigate the effects of alloxan on glucose metabolism by islet cells. 


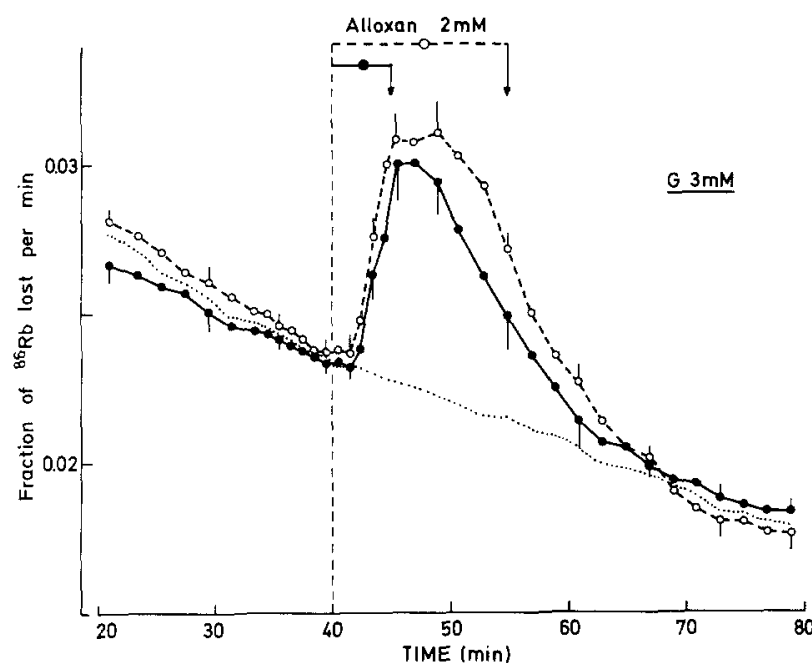

Fig. 1. Effect of alloxan on ${ }^{86} \mathrm{Rb}$ efflux from rat islets perifused in the presence of $3 \mathrm{mmol} / \mathrm{l}$ glucose throughout. The stippled line shows the rate of ${ }^{86} \mathrm{Rb}$ efflux from control islets not treated with alloxan. As indicated by the arrows, alloxan ( $2 \mathrm{mmol} / \mathrm{l})$ was added for $5 \mathrm{~min}$ (40-45 $\mathrm{min}-0)$ or $15 \mathrm{~min}$ (40-55 ०---0). In the lastmentioned series of experiments, a new medium with freshly dissolved alloxan was used every $5 \mathrm{~min}$. Values are means \pm SEM of 4 experiments

\section{Materials and Methods}

\section{Animals and Solutions}

All experiments were performed with islets isolated from male Wistar rats (275-325 g) kept on a standard pellet diet and tap water ad libitum. They were killed $3 \mathrm{~h}$ after intraperitoneal injection of pilocarpine $(20 \mathrm{mg} / \mathrm{kg})$. The islets were obtained by combining mild collagenase digestion of the gland ( $5 \mathrm{mg}$ collagenase per pancreas and shaking for 3.5 to $4 \mathrm{~min}$ ) and microdissection of the partially digested pieces. Control experiments have shown that pretreatment of the animals with this dose of pilocarpine did not significantly alter the insulin response of the isolated islets to various secretagogues.

The medium utilized was Krebs-Ringer bicarbonate buffer [18], $\mathrm{pH} 7.4$, gassed with $\mathrm{O}_{2} / \mathrm{CO}_{2}(94: 6)$, supplemented with $0.5 \%$ $(\mathrm{w} / \mathrm{v})$ bovine serum albumin and containing $3 \mathrm{mmol} / 1$ glucose in basal conditions. For metabolic studies, $10 \mathrm{mmol} / 1$ HEPES ( $N$-2hydroxyethylpiperazine- $N$-2-ethanesulfonic acid) was added to the medium to prevent any change of $\mathrm{pH}$ in the small volumes of solutions used in these experiments. Because of rapid inactivation at $37^{\circ} \mathrm{C}$, alloxan $(2 \mathrm{mmol} / \mathrm{l})$ was dissolved in the appropriate prewarmed medium immediately prior to use. This concentration of alloxan decreased the $\mathrm{pH}$ of the buffer by less than 0.2 units and a 5 min treatment with a medium acidified to 7.2 (by addition of $\mathrm{HCl}$ ) did not affect the islet responses. Control experiments were also carried out with inactivated alloxan $\left(3 \mathrm{~h}\right.$ in solution at $37^{\circ} \mathrm{C}$ before use).

\section{Measurements of Insulin Release, Rubidium Efflux and Glucose Metabolism}

The perifusion technique utilized to study insulin release and the method for measurement of immunoreactive insulin (IRI) have been previously reported [18].
The technique to monitor the efflux of ${ }^{86} \mathrm{Rb}$ from preloaded islets was similar to that recently described $[10,14]$. Briefly, groups of 60 to 90 islets were first loaded with ${ }^{86} \mathrm{Rb}$ by incubation for $150 \mathrm{~min}$ in $0.5 \mathrm{ml}$ basal medium supplemented with $0.2 \mathrm{mmol} / 1$ ${ }^{86} \mathrm{RbCl}$. They were then washed three times with $2 \mathrm{ml}$ nonradioactive medium and placed in the perifusion chambers $(0.3 \mathrm{ml})$, to which the perifusate, at $37^{\circ} \mathrm{C}$, was conveyed at a rate of $1.1 \mathrm{ml} / \mathrm{min} .{ }^{86} \mathrm{Rb}$ in the effluent fractions (collected at 1 or 2 min intervals; 1500 to $15000 \mathrm{cpm}$ per fraction) and remaining in the islets at the end of the experiment was counted by the Cerenkov radiation $[10,16]$. For each collection interval, the fractional efflux of ${ }^{86} \mathrm{Rb}\left({ }^{86} \mathrm{Rb}\right.$ released during time interval $/{ }^{86} \mathrm{Rb}$ remaining in tissue during that time interval) was calculated.

Glucose utilization by islet cells was measured by the production of $\left[{ }^{3} \mathrm{H}\right]$-water from $\mathrm{D}-\left[5_{-}^{3} \mathrm{H}\right]$ glucose [19] and glucose oxidation by the conversion of $\mathrm{D}-\left[\mathrm{U}_{-}{ }^{14} \mathrm{C}\right]$ glucose to $\left[{ }^{14} \mathrm{C}\right]-\mathrm{CO}_{2}$. Pools of islets were first preincubated at $37^{\circ} \mathrm{C}$ in $10 \mathrm{ml}$ medium containing glucose alone $(3 \mathrm{mmol} / \mathrm{l})$ or with 3 - 0 -methylglucose $(20 \mathrm{mmol} / \mathrm{l})$. After $25 \mathrm{~min}, 5 \mathrm{ml}$ of the same prewarmed medium with or without $6 \mathrm{mmol} / 1$ freshly dissolved alloxan was added; in the test groups the final concentration of alloxan was thus $2 \mathrm{mmol} / \mathrm{l}$. Five min later, the islets were rapidly and extensively washed at room temperature before being transferred to the incubation tubes for $1 \mathrm{~h}$ at $37^{\circ} \mathrm{C}$ in the following conditions: (a) utilization studies: 10 islets in $20 \mu \mathrm{l}$ of medium containing 3 or $15 \mathrm{mmol} / 1 \mathrm{D}-\left[5-{ }^{3} \mathrm{H}\right]$ glucose ( 2.5 and $0.5 \mathrm{mCi} / \mathrm{mmol}$, respectively). b) oxidation studies: 10 islets in $50 \mu \mathrm{l}$ of medium containing 3 or $15 \mathrm{mmol} / 1 \mathrm{D}-\left[\mathrm{U}_{-}{ }^{14} \mathrm{C}\right]-$ glucose ( 6 and $1.2 \mathrm{mCi} / \mathrm{mmol}$, respectively). Other technical aspects of these methods have been described elsewhere [18].

\section{Chemicals}

Alloxan monohydrate, 3-0-methyl-D-glucose and $\alpha$-ketoisocaproic acid were obtained from Sigma Chemical Co., St. Louis, Mo., USA; HEPES was from British Drug Houses, Poole, Dorset, U. K.; D-glyceraldehyde was from Koch-Light Laboratories Ltd., Colnbrook Bucks, U. K.; collagenase (type IV; $200 \mathrm{U} / \mathrm{mg}$ ) was from Worthington Biochemical Co., Freehold, N. J., USA; tolbutamide was supplied by Hoechst Research Laboratories, Frankfurt/Main, Germany. All other reagents were of analytical grade and purchased from Merck A. G., Darmstadt, Germany. The radioactive isotopes ${ }^{86} \mathrm{RbCl}(330-510 \mathrm{mCi} / \mathrm{mmol}), \mathrm{D}-\left[\mathrm{U}-{ }^{14} \mathrm{C}\right]$ glucose $(327 \mathrm{mCi} / \mathrm{mmol})$ and $\mathrm{D}-\left[5-{ }^{3} \mathrm{H}\right]$ glucose $(1 \mathrm{Ci} / \mathrm{mmol})$ were obtained from the Radiochemical Centre, Amersham, U. K.

\section{Presentation of Results}

All results are expressed as means \pm SEM. The statistical significance of differences between experimental groups was assessed by Student's $t$ test for unpaired data and the Wilcoxon rank-sum test.

\section{Results}

\section{Effect of Alloxan at a Low Glucose Concentration}

In control islets perifused with a medium containing $3 \mathrm{mmol} / 1$ glucose, the rate of ${ }^{86} \mathrm{Rb}$ efflux slowly decreased with time (Fig. 1). Exposure of the islets to $2 \mathrm{mmol} / \mathrm{l}$ alloxan for $5 \mathrm{~min}$, at the same glucose concentration, had no significant effect on insulin release (not illustrated), but increased the rate of ${ }^{86} \mathrm{Rb}$ efflux. This increase in efflux rate was transient, even when 

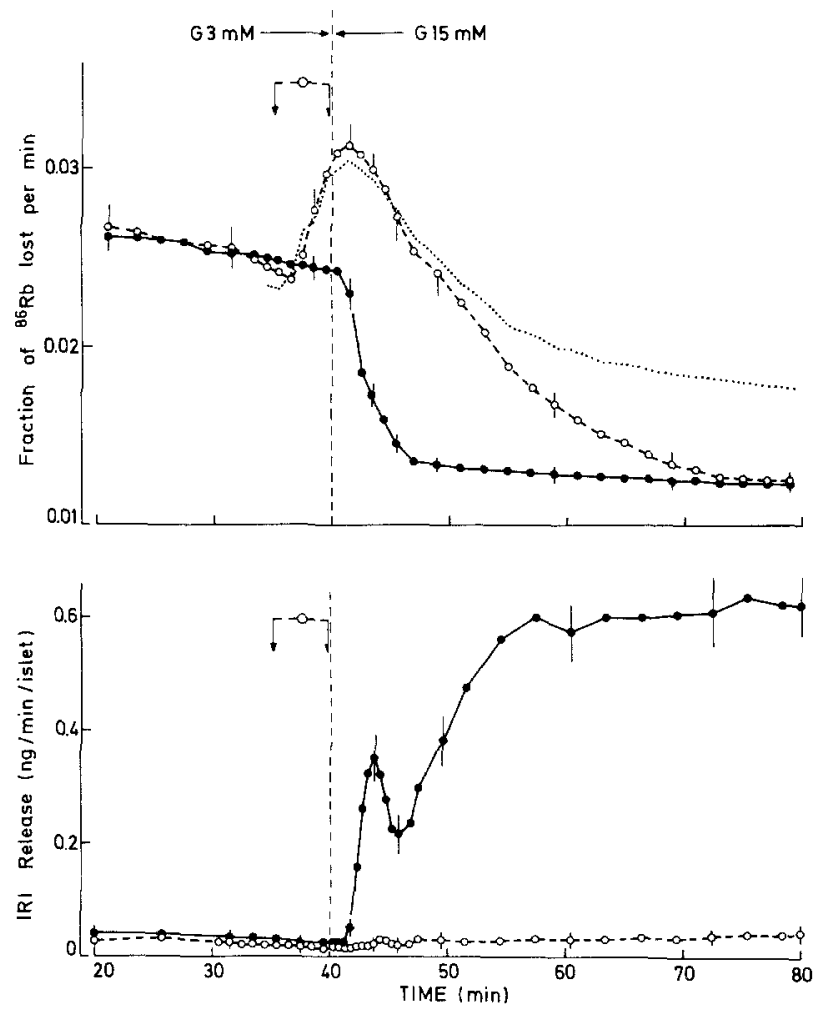

Fig. 2. Effect of alloxan on the reduction of ${ }^{86} \mathrm{Rb}$ efflux (upper panel) and the stimulation of insulin (IRI) release (lower panel) by glucose. Glucose concentration was increased from 3 to $15 \mathrm{mmol} / 1$ from 40 to $80 \mathrm{~min}$. As indicated by the vertical arrows, alloxan ( 2 $\mathrm{mmol} / \mathrm{l})$ was added for $5 \mathrm{~min}(35-400---0)$. In this and all the following figures, the stippled line in the upper panel shows the rate of ${ }^{86} \mathrm{Rb}$ efflux from islets treated with alloxan between min 35 and 40 and maintained in $3 \mathrm{mmol} / 1$ glucose during the whole experiment. Values are means \pm SEM of 4 experiments for ${ }^{86} \mathrm{Rb}$ efflux and 5 experiments for insulin release

alloxan remained present for $15 \mathrm{~min}$ (a freshly prepared solution was used every $5 \mathrm{~min}$ ).

\section{Effect of Alloxan on Glucose Stimulation}

As shown in Fig. 2, stimulation with $15 \mathrm{mmol} / 1$ glucose produced a marked fall in the rate of ${ }^{86} \mathrm{Rb}$ efflux from control islets (upper panel) and a concomitant biphasic increase in insulin release (lower panel). Alloxan treatment for the last $5 \mathrm{~min}$ preceding glucose stimulation abolished insulin secretion (lower panel) and prevented glucose from rapidly decreasing the K-permeability in the islet cells. Thus, during the first $15 \mathrm{~min}$ of stimulation with $15 \mathrm{mmol} / 1 \mathrm{glu}-$ cose, the rate of ${ }^{86} \mathrm{Rb}$ efflux remained the same as in the presence of $3 \mathrm{mmol} / \mathrm{l}$ glucose; however, it finally reached the same low level as in control islets after 30 min of stimulation (Fig. 2, upper panel). Treatment of the islets with inactivated alloxan in the presence of $3 \mathrm{mmol} / 1$ glucose had no effect on ${ }^{86} \mathrm{Rb}$
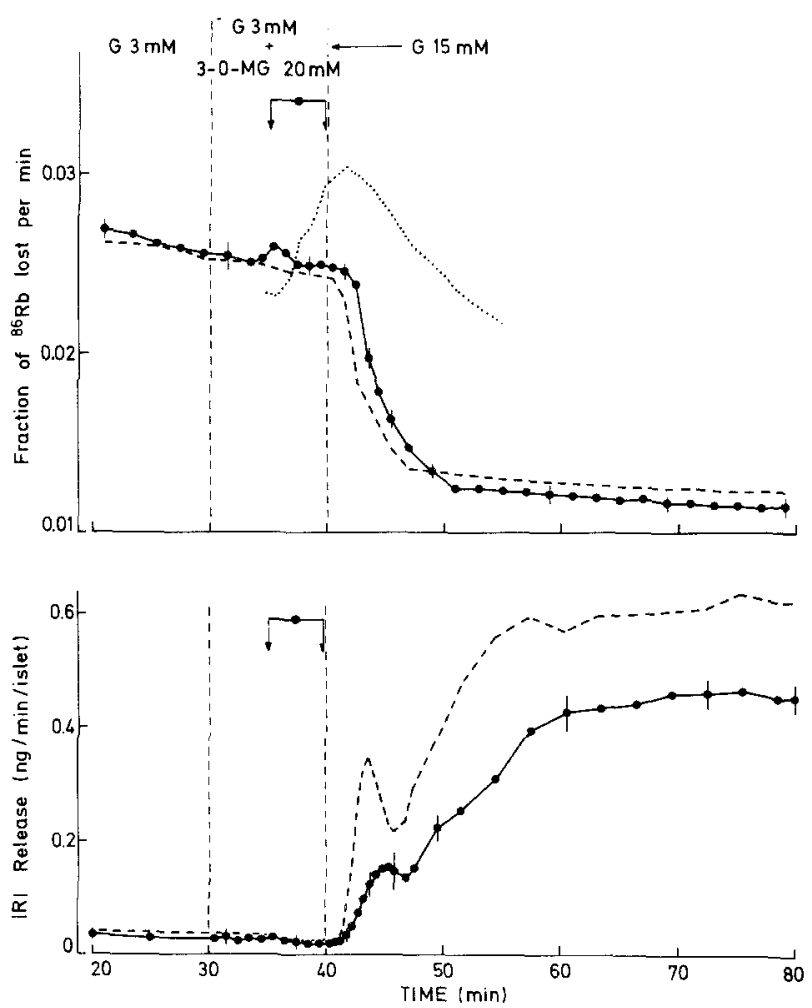

Fig. 3. 3- 0 -Methylglucose (3-0-MG) protection against alloxan alteration of the reduction of ${ }^{86} \mathrm{Rb}$ efflux (upper panel) and the stimulation of insulin (IRI) release (lower panel) by glucose. Glucose concentration was increased from 3 to $15 \mathrm{mmol} / 1$ from 40 to $80 \mathrm{~min}$. 3-0-MG (20 mmol/l) was present $5 \mathrm{~min}$ before and during alloxan treatment. As indicated by the vertical arrows, alloxan ( 2 $\mathrm{mmol} / \mathrm{l})$ was added for $5 \mathrm{~min}(35-40)$. The broken lines in upper and lower panels show the control effect of $15 \mathrm{mmol} / 1$ glucose, without prior alloxan treatment. The stippled line in the upper panel as in Fig. 2. Values are means \pm SEM of 4 experiments for ${ }^{86} \mathrm{Rb}$ efflux and 5 experiments for insulin release

efflux and did not alter the effect of a high glucose concentration (not shown).

Exposure of the islets simultaneously to $2 \mathrm{mmol} / 1$ alloxan (for $5 \mathrm{~min}$ ) and $15 \mathrm{mmol} / 1$ glucose only resulted in a partial decrease in the insulin-releasing effect of the sugar. The first and second phases of insulin release were inhibited by 59 and $51 \%(\mathrm{P}<$ $0.005, \mathrm{n}=5$ ), respectively. In these conditions, ${ }^{86} \mathrm{Rb}$ efflux rate was not increased by alloxan but was reduced by high glucose, as in control islets (the fraction of ${ }^{86} \mathrm{Rb}$ lost per minute was $0.0170 \pm 0.0005$ after $5 \mathrm{~min}$ of $15 \mathrm{mmol} / \mathrm{l}$ glucose and $2 \mathrm{mmol} / \mathrm{l}$ alloxan together, as compared to $0.0166 \pm 0.0003$ after $5 \mathrm{~min}$ of $15 \mathrm{mmol} / \mathrm{l}$ glucose alone; $\mathrm{n}=3$ ).

In the experiments illustrated in Fig. 3, 3- 0 methylglucose $(20 \mathrm{mmol} / \mathrm{l})$ was added to the perifusate $5 \mathrm{~min}$ before alloxan and was maintained during the $5 \mathrm{~min}$ of exposure to the drug. The presence of 3-0-methylglucose did not change basal insulin release, but provided partial protection against inhi- 

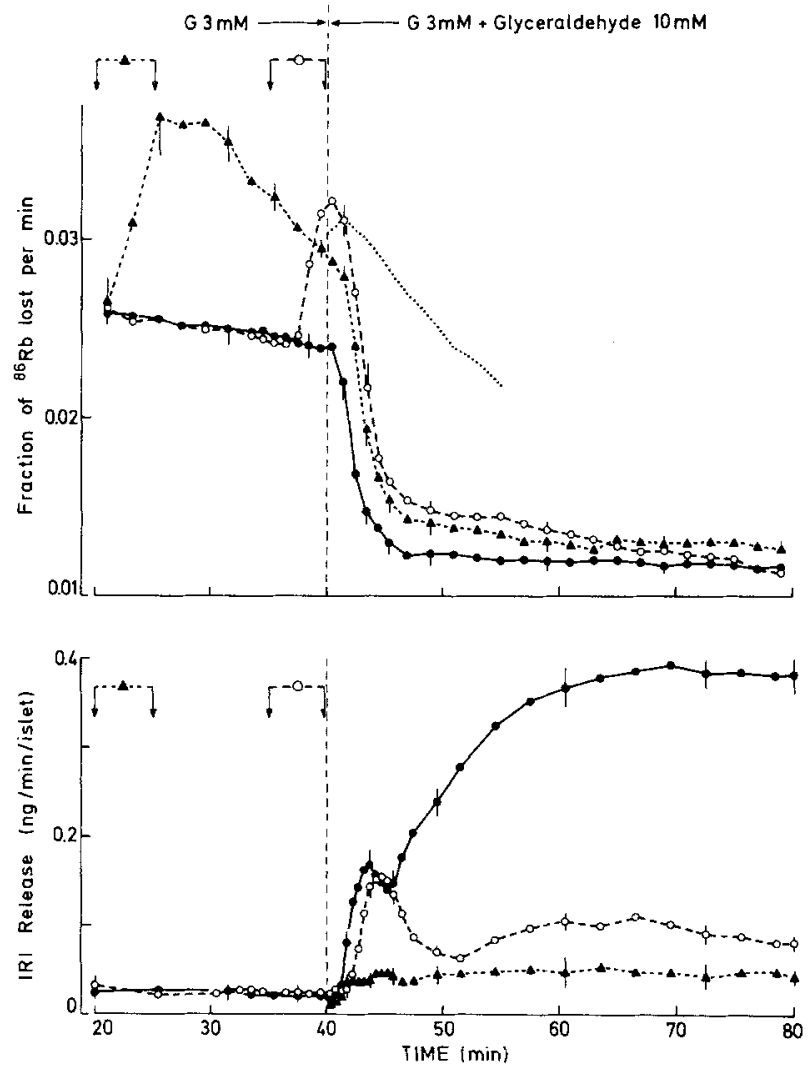

Fig. 4. Effect of alloxan on the reduction of ${ }^{86} \mathrm{Rb}$ efflux (upper panel) and the stimulation of insulin (IRI) release (lower panel) by D-glyceraldehyde. Glucose concentration was $3 \mathrm{mmol} / \mathrm{l}$ throughout and D-glyceraldehyde $(10 \mathrm{mmol} / \mathrm{l})$ was present from 40 to $80 \mathrm{~min}$. As indicated by the vertical arrows, alloxan $(2 \mathrm{mmol} / \mathrm{l})$ was added for $5 \min (20-25 \boldsymbol{\Delta} \cdots \cdots \cdot$. $)(35-40 \quad 0--0)$. The stippled line in the upper panel as in Fig. 2. Values are means \pm SEM of 5 control and 3 alloxan experiments for ${ }^{86} \mathrm{Rb}$ efflux and of 8 control and 5 alloxan experiments for insulin release

bition of the glucose effect by alloxan (Fig. 3, lower panel). The first and second phases of insulin secretion were inhibited by 57 and $32 \%$ respectively $(\mathrm{P}<$ 0.01 and $\mathrm{P}<0.02, \mathrm{n}=5$ ). 3- 0 -Methylglucose itself did not alter the rate of ${ }^{86} \mathrm{Rb}$ efflux from the islets, but prevented the increased efflux otherwise produced by alloxan. It also protected the ability of a high glucose concentration to reduce ${ }^{86} \mathrm{Rb}$ efflux rapidly (Fig. 3, upper panel). However, the changes in ${ }^{86} \mathrm{Rb}$ efflux and insulin release produced by 15 $\mathrm{mmol} / \mathrm{l}$ glucose after exposure to alloxan together with 3-O-methylglucose were slightly delayed as compared to controls.

\section{Effect of Alloxan on D-Glyceraldehyde Stimulation}

In control islets, $10 \mathrm{mmol} / 1$ glyceraldehyde produced a rapid decrease in ${ }^{86} \mathrm{Rb}$ efflux and a simultaneous biphasic release of insulin (Fig. 4). Alloxan treatment
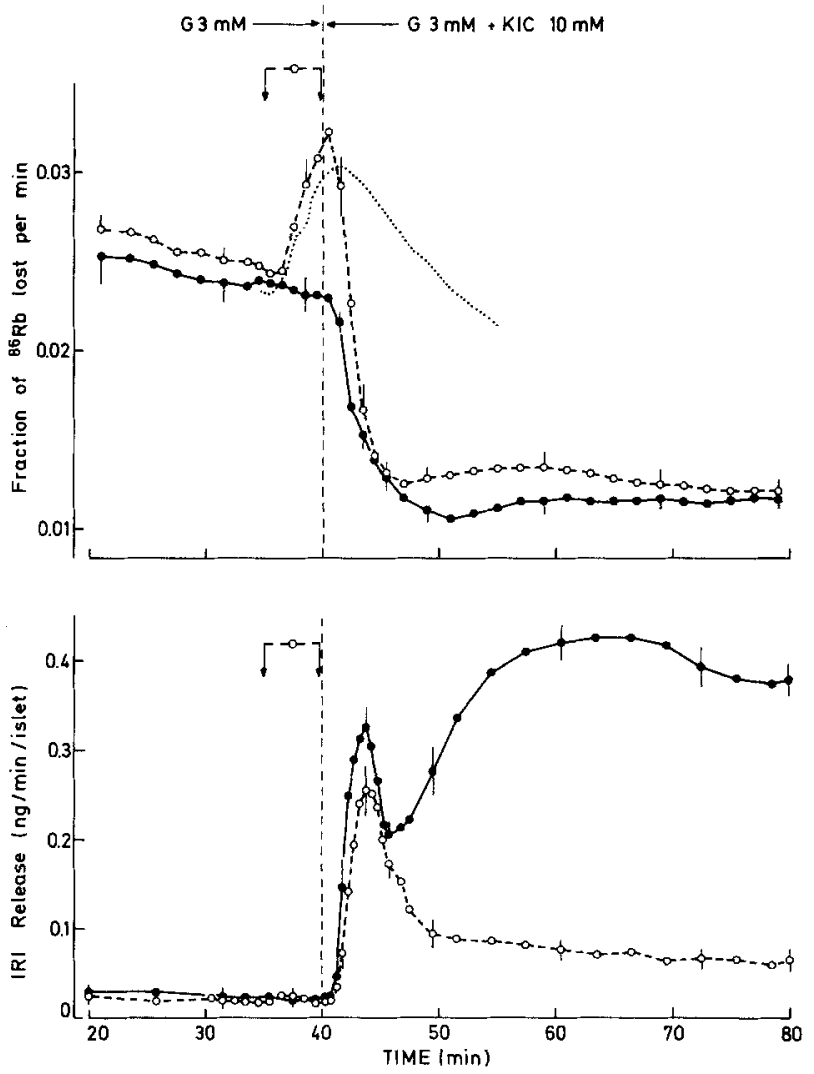

Fig. 5. Effect of alloxan on the reduction of ${ }^{86} \mathrm{Rb}$ efflux (upper panel) and the stimulation of insulin (IRI) release (lower panel) by $\alpha$-ketoisocaproic acid (KIC). Glucose concentration was $3 \mathrm{mmol} / 1$ throughout and $\alpha$-ketoisocaproic acid $(10 \mathrm{mmol} / \mathrm{l})$ was present from 40 to $80 \mathrm{~min}$. As indicated by the vertical arrows, alloxan (2 $\mathrm{mmol} / \mathrm{l})$ was added for $5 \mathrm{~min}(35-400--0)$. The stippled line in the upper panel as in Fig. 2. Values are means \pm SEM of 3 experiments for ${ }^{86} \mathrm{Rb}$ efflux and 4 experiments for insulin release

during the last 5 min preceding stimulation delayed the early phase of release induced by the triose and markedly inhibited the late phase. If similar exposure to alloxan occurred earlier in the washing period and was followed by $15 \mathrm{~min}$ in basal medium, glyceraldehyde stimulation was almost ineffective (Fig. 4, lower panel, and Table 1). On the other hand, Fig. 4 (upper panel) shows that the rate of ${ }^{86} \mathrm{Rb}$ efflux, increased by alloxan, was quickly reduced upon addition of glyceraldehyde. This effect, although somewhat delayed as compared to controls, occurred much earlier than after stimulation with $15 \mathrm{mmol} / \mathrm{l}$ glucose (compare with Fig. 2) and was present even when the secretory response was almost suppressed.

The presence of 3-0-methylglucose during alloxan treatment completely protected the islets against inhibition of the insulinotropic action of glyceraldehyde (Table 1). The two phases of insulin release stimulated by glyceraldehyde were reduced by about $40 \%$ when no glucose was present in the medium and 
were almost completely abolished if alloxan exposure occurred in these conditions (Table 1).

\section{Effect of Alloxan}

on $\alpha$-ketoisocaproic Acid Stimulation

Stimulation with $\alpha$-ketoisocaproic acid $(10 \mathrm{mmol} / \mathrm{l})$ resulted in a concomitant decrease in the rate of ${ }^{86} \mathrm{Rb}$ efflux and a biphasic increase in insulin secretion (Fig. 5). Immediately after exposure of the islets to alloxan, $\alpha$-ketoisocaproic acid still induced a slightly smaller rapid phase of insulin release $(0.80 \pm 0.05$ $\mathrm{ng} /$ islet vs $1.08 \pm 0.08 \mathrm{ng} /$ islet in controls, $\mathrm{P}<0.05$, $\mathrm{n}=4$ ) followed by a markedly depressed late phase (lower panel) and remained able to reduce rapidly the rate of ${ }^{86} \mathrm{Rb}$ efflux (upper panel).

\section{Effect of Alloxan on Tolbutamide Stimulation}

At the glucose concentration used $(3 \mathrm{mmol} / \mathrm{l})$, tolbutamide $(200 \mu \mathrm{g} / \mathrm{ml})$ stimulated a monophasic release of insulin and decreased the rate of ${ }^{86} \mathrm{Rb}$ efflux (Fig. 6). Alloxan treatment of the islets immediately before stimulation did not significantly affect the releasing action of the sulphonylurea (1.04 $\pm 0.08 \mathrm{ng} /$ islet, $\mathrm{n}=5$ vs. $1.21 \pm 0.05 \mathrm{ng} /$ islet in controls, $\mathrm{n}=8$ ). By contrast, the insulin response to tolbutamide was markedly reduced $(0.40 \pm 0.05 \mathrm{ng} /$ islet, $\mathrm{n}=5, \mathrm{P}<0.001$ ) if similar exposure to alloxan had occurred earlier in the washing period (lower panel). In addition, in a glucose-free medium, a 5 min treatment of the islets with alloxan inhibited the releasing effect of tolbutamide when tested $15 \mathrm{~min}$ later $(0.17 \pm 0.03 \mathrm{ng} /$ islet vs $0.37 \pm 0.06 \mathrm{ng} /$ islet in controls, $\mathrm{P}<0.02, \mathrm{n}=5$ ). As shown in the upper panel of Fig. 6 , the rapid reduction in ${ }^{86} \mathrm{Rb}$
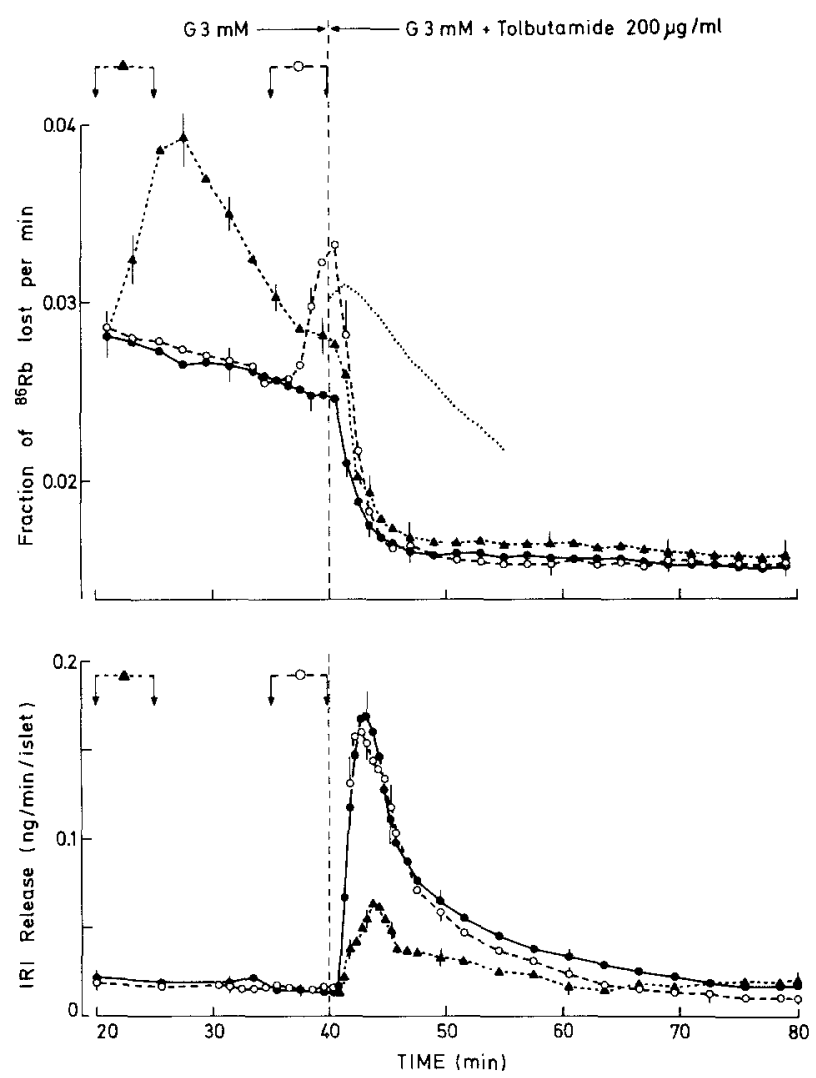

Fig. 6. Effect of alloxan on the reduction of ${ }^{86} \mathrm{Rb}$ efflux (upper panel) and the stimulation of insulin (IRI) release (lower panel) by tolbutamide. Glucose concentration was $3 \mathrm{mmol} / 1$ throughout and tolbutamide $(200 \mu \mathrm{g} / \mathrm{ml})$ was present from 40 to $80 \mathrm{~min}$. As indicated by the vertical arrows, alloxan $(2 \mathrm{mmol} / \mathrm{l})$ was added for $5 \min (20-25 \boldsymbol{\Delta} \cdots \cdots \boldsymbol{\Delta})(35-400-\cdots)$. The stippled line in the upper panel as in Fig. 2. Values are means \pm SEM of 5 control and 3 alloxan experiments for ${ }^{86} \mathrm{Rb}$ efflux and of 8 control and 5 alloxan experiments for insulin release

Table 1. Effect of alloxan on the stimulation of insulin release by D-glyceraldehyde

\begin{tabular}{|c|c|c|c|c|c|c|}
\hline \multirow{2}{*}{ Exp } & \multirow{2}{*}{ n } & \multicolumn{3}{|c|}{ Experimental conditions (mmol/l) } & \multicolumn{2}{|c|}{ IRI release during stimulation ( $\mathrm{ng} / \mathrm{islet}$ ) } \\
\hline & & Glucose & Alloxan & 3-0-methylglucose & $40.5-46 \mathrm{~min}$ & $46-80 \mathrm{~min}$ \\
\hline 1 & 5 & 0 & 0 & 0 & $0.34 \pm 0.03$ & $6.70 \pm 0.44$ \\
\hline 2 & 3 & 0 & 2 & 0 & $0.02 \pm 0.00^{\mathrm{a}}$ & $0.35 \pm 0.05^{\mathrm{a}}$ \\
\hline 3 & 8 & 3 & 0 & 0 & $0.57 \pm 0.04^{b}$ & $11.11 \pm 0.45^{\mathrm{a}}$ \\
\hline 4 & 6 & 3 & 2 & 0 & $0.10 \pm 0.02^{a, c}$ & $1.36 \pm 0.35^{\mathrm{a}, \mathrm{c}}$ \\
\hline 5 & 4 & 3 & 2 & 20 & $0.44 \pm 0.06^{\mathrm{d}}$ & $10.46 \pm 1.02^{\mathrm{d}}$ \\
\hline
\end{tabular}

Immediately after isolation groups of 30 islets were transferred into the perifusion chambers for $80 \mathrm{~min}$. Glyceraldehyde (10 mmol/l) was added to the medium from min 40 to 80 . The glucose concentration indicated in the table remained the same throughout. Alloxan treatment lasted $5 \mathrm{~min}(\mathrm{~min} 20-25)$

In experimental series 5,3-0-methylglucose was present 5 min before and after as well as during alloxan treatment, thus from min 15 to 30 Values are means \pm SEM of $\mathrm{n}$ experiments. Significance levels: ${ }^{\mathrm{a}} \mathrm{P}<0.001$ vs $\operatorname{Exp} 1 ;{ }^{\mathrm{b}} \mathrm{P}<0.01$ vs $\operatorname{Exp} 1 ;{ }^{\mathrm{c}} \mathrm{P}<0.001$ vs $\operatorname{Exp} 3 ;{ }^{\mathrm{d}} \mathrm{NS}$, $\mathrm{P}>0.05 v s \operatorname{Exp} 3$ 
Table 2. Effect of alloxan on glucose metabolism by isolated islets

\begin{tabular}{lcc}
\hline $\begin{array}{l}\text { Experimental } \\
\text { conditions } \\
\text { during } \\
\text { preincubation } \\
\text { (mmol/1) }\end{array}$ & $\begin{array}{l}\text { Glucose utilized } \\
\text { (pmol/h/islet) }\end{array}$ & $\begin{array}{l}\text { Glucose oxidized } \\
\text { (pmol/h/islet) }\end{array}$ \\
\hline \multicolumn{4}{c}{} \\
Controls & Glucose $3 \mathrm{mmol} / \mathrm{l}$ \\
Alloxan (2) & $35.0 \pm 0.9(8)$ & $11.1 \pm 0.9(8)$ \\
& $17.5 \pm 0.9^{\mathrm{a}}(8)$ & $5.6 \pm 0.7^{\mathrm{a}}(8)$ \\
& & \\
Controls & Glucose $15 \mathrm{mmol} / \mathrm{l}$ & \\
Alloxan (2) & $141.3 \pm 4.3(11)$ & $44.8 \pm 2.5(11)$ \\
Alloxan (2) + & $64.7 \pm 2.7^{\mathrm{a}}(11)$ & $25.3 \pm 2.5^{\mathrm{a}}(11)$ \\
3-0-methylglucose (20) & $115.8 \pm 3.2^{\mathrm{b}}(9)$ & $42.6 \pm 2.1(9)$ \\
\hline
\end{tabular}

Values are means \pm SEM of the number of batches of islets given in parentheses. Significance levels: a $\mathrm{P}<0.001$ vs appropriate controls at the same glucose concentration; ${ }^{b} \mathrm{P}<0.001$ vs controls and alloxan alone, in the presence of $15 \mathrm{mmol} / 1$ glucose

efflux by tolbutamide persisted after alloxan treatment, even when secretion of insulin was inhibited.

\section{Effect of Alloxan on Glucose Metabolism}

In vitro treatment of the islets for $5 \mathrm{~min}$ with $2 \mathrm{mmol} / \mathrm{l}$ alloxan in the presence of $3 \mathrm{mmol} / 1$ glucose reduced glucose utilization and oxidation by roughly $50 \%$ both at a low $(3 \mathrm{mmol} / \mathrm{l})$ and a high $(15 \mathrm{mmol} / \mathrm{l})$ glucose concentration (Table 2 ). The presence of $3-$ 0 -methylglucose $(20 \mathrm{mmol} / \mathrm{l})$ during exposure to alloxan afforded partial protection of glucose utilization and complete protection of glucose oxidation.

\section{Discussion}

\section{Effect of Alloxan on Insulin Release}

In contrast to the well documented alloxan inhibition of glucose-stimulated insulin release, the effects of the drug on the response to other secretagogues have not been extensively studied. It has been reported that, after alloxan treatment in vitro, the rapid release of insulin stimulated by tolbutamide is preserved [17], whereas the response to leucine is partially inhibited [20]. The effects of alloxan on the stimulation by glyceraldehyde do not seem to have been investigated. It is known, however, that neither glyceraldehyde nor tolbutamide protects against the in vivo diabetogenic action of alloxan [21] nor against the in vitro alteration of glucose-stimulated insulin release [22] and proinsulin biosynthesis [23].

The present experiments demonstrate that the secretory response of B-cells to different stimuli is not uniformly impaired immediately after alloxan. As previously reported [17] treatment of the islets with the drug during the $5 \mathrm{~min}$ immediately preceding stimulation is sufficient to abolish the response to glucose. By contrast, tolbutamide, glyceraldehyde and $\alpha$-ketoisocaproic acid remain able to induce an almost normal rapid release after such treatment, the second phase of secretion stimulated by the two latter secretagogues being clearly reduced. Yet the differential effect of alloxan on the rapid and late phases of insulin release is only apparent. Thus, the early responses to tolbutamide and glyceraldehyde were also markedly inhibited if the stimulation was applied 15 min after alloxan treatment.

Since these experiments were carried out in the presence of $3 \mathrm{mmol} / \mathrm{l}$ glucose, the possibility was considered that the effect of the secretagogue itself was not markedly affected by alloxan, but that only the potentiation by the low glucose concentration was suppressed. Such a view is unlikely to explain the effects on $\alpha$-ketoisocaproic acid stimulation, since the releasing properties of this leucine derivative are not augmented by a low glucose concentration [24]. Furthermore, it cannot account for the effect of alloxan on glyceraldehyde or tolbutamide stimulation; thus, the release of insulin induced by the triose in complete absence of glucose is also inhibited by alloxan and is much higher than that occurring after alloxan treatment in $3 \mathrm{mmol} / \mathrm{l}$ glucose (Table 2). Similarly, the insulin response to tolbutamide in a glucose-free medium is decreased by alloxan.

It appears that glucose stimulation of insulin release is by far the most sensitive to alloxan damage, but that the drug also produces a delayed inhibition of release when stimulated by agents structurally unrelated to glucose.

\section{Effect of Alloxan on Rubidium Efflux}

Because of its longer half-life, ${ }^{86} \mathrm{Rb}$ is a convenient substitute for ${ }^{42} \mathrm{~K}$, particularly when qualitative changes in the K-permeability are studied $[10,14$, 16]. At a low glucose concentration, neither ${ }^{42} \mathrm{~K}$ [10] nor ${ }^{86} \mathrm{Rb}$ efflux from the islet cells follows simple exponential kinetics (which would give a horizontal curve with the present mode of expression). The present experiments confirm that glucose $[10,11,14]$ and tolbutamide [25] markedly reduce the potassium permeability in islet cells. They further demonstrate that the same effect is produced by glyceraldehyde and $\alpha$-ketoisocaproic acid. This suggests that the four agents (provided $\alpha$-ketoisocaproic acid has the same electrical properties as leucine) depolarize B cells $[26,27]$ by a similar mechanism.

By contrast, exposure of the islets to alloxan produced an increase in the rate of ${ }^{86} \mathrm{Rb}$ efflux prevented by a high concentration of 3-0-methylglucose or glu- 
cose. Such an effect of alloxan was not found in islets of ob/ob mice [6], probably because measurements of the amount of ${ }^{86} \mathrm{Rb}$ retained in the tissue are not sensitive enough to detect a transient increase in ${ }^{86} \mathrm{Rb}$ efflux. Although this increase in K-permeability could conceivably be the result of damage to the cell membrane, several arguments do not support this possibility: (a) the effect is transient even when alloxan is present for $15 \mathrm{~min}$; (b) it is not accompanied by a leak of insulin in our system; (c) a similar dose of alloxan does not augment the permeability of rat islet cell membranes to sucrose [9]; and $(d)$ it is quickly reversed by glyceraldehyde, tolbutamide and $\alpha$ ketoisocaproic acid. We would suggest rather that the blockade [6] of an electrogenic $\mathrm{Na} / \mathrm{K}$ pump [27] is, at least partially, the cause of the depolarization measured in alloxan treated B-cells [5] and that the increase in ${ }^{86} \mathrm{Rb}$ efflux is the consequence of this fall in membrane potential. The possible interrelationships between ionic, electrical and metabolic changes produced by alloxan are difficult to evaluate. For instance, an arrest of the $\mathrm{Na} / \mathrm{K}$ pump can theoretically be the cause as well as the consequence of decreased metabolism. However, the depolarization of B-cells produced by alloxan is not expected to result from an impaired energy production, since classical uncouplers or inhibitors of glucose metabolism hyperpolarize B-cells $[12,28]$. A direct effect of alloxan on the $\mathrm{Na} / \mathrm{K}$ pump is thus plausible [6].

Similar to its insulin releasing properties, the ability of glucose to reduce K-permeability in islet cells appears exquisitely sensitive to alloxan. Thus, among the four agents tested, only glucose was unable to reduce rapidly ${ }^{86} \mathrm{Rb}$ efflux from islets initially exposed to alloxan. Since normal glucose metabolism is required for glucose to decrease K-permeability [10], alloxan-induced metabolic alterations might be involved. In several experimental conditions alloxan barely affected the ability of secretagogues to reduce $\mathrm{K}$-permeability in islet cells, whereas it markedly altered their insulin releasing effect. Such a dissociation has also been found in the absence of extracellular calcium [10] and suggests that the alloxan block of insulin release is not at the earliest steps of stimulussecretion coupling. However, a complete understanding of the mechanisms underlying secretagogueinduced changes in K-permeability is obviously needed to propose a rational explanation of the present observations.

\section{Effect of Alloxan on Glucose Metabolism}

The present results clearly show that a brief alloxan treatment in vitro severely alters both glucose utilization ("glycolysis") and oxidation in islet cells. 3- 0 Methylglucose protects against this deleterious effect, which cannot be accounted for by a reduced glucose transport in islet cells [9]. An impairment of glucose oxidation by mouse islets has also been reported after in vivo treatment of the animals with alloxan [29] or in vitro exposure of the islets to the drug [30]. It is clear, however, that detailed time course studies are necessary to establish whether there is a causal relationship between the alteration of glucose metabolism and the inhibition of insulin release. Nevertheless, these observations and the evidence of a strong inhibition of proinsulin biosynthesis in isolated islets after in vivo [31] or in vitro [23, 32] treatment by alloxan show that, besides its membrane effects, alloxan also has intracellular effects.

\section{Mechanism of Alloxan Action}

Although it remains difficult to propose a complete model of the effects of alloxan, the following suggestions can be made. The recognition of glucose by Bcells is more rapidly and more severely affected by alloxan than the recognition of other secretagogues. However, after some delay, their releasing effect is markedly impaired, without B-cells being totally unresponsive, since the decrease in K-permeability is only marginally affected. It does not appear possible to explain these observations by an action of alloxan restricted to a putative membrane glucoreceptor. The possibility should be considered that alloxan enters B-cells $[33,34]$ via the hexose carrier system where antagonists of glucose transport (3-0-methylglucose, cytochalasin $\mathrm{B}$, phlorizin) exert their protective action [4, 17, 21, 34-36]. Alloxan would then interfere with cellular events crucial for the response to glucose and subsequently lead to a more general dysfunctioning of the releasing machinery.

Acknowledgements. We are grateful to B. Debie, B. Moos and M. Nenquin for skilled technical assistance, to M. Detaille and M. Nenquin for editorial help and to Prof. D. P. Cameron for helpful discussions. J. C. H. is "Chargé de Recherches" from the Fonds National de la Recherche Scientifique, Brussels. These studies were supported by grant 3.4509 .75 from the Fonds de la Recherche Scientifique Médicale, Brussels and by a grant-in-aid from Hoechst-Belgium S. A.

\section{References}

1. Rerup, C. C.: Drugs producing diabetes through damage of the insulin secreting cells. Pharmacol. Rev. 22, 485-518 (1970)

2. Bhattacharya, G.: On the protection of alloxan diabetes by hexoses. Science 120, 841-843 (1954)

3. Scheynius, A., Täljedal, I.-B.: On the mechanism of glucose protection against alloxan toxicity. Diabetologia 7, 252-255 (1971)

4. Cooperstein, S. J., Watkins, D.: Effect of sulphydryl-binding reagents on islet tissue permeability: protection and reversal 
by D-glucose and phlorizin. J. Pharmacol. Exp. Ther. 204, 230-239 (1978)

5. Dean, P. M., Matthews, E. K.: The bioelectrical properties of pancreatic islet cells: effect of diabetogenic agents. Diabetologia 8, 173-178 (1972)

6. Idahl, L.-A., Lernmark, A., Sehlin, J., Täljedal, I. B.: Alloxan cytotoxicity in vitro: inhibition of rubidium ion pumping in pancreatic $\beta$-cells. Biochem. J. 162, 9-18 (1977)

7. Orci, L., Amherdt, M., Malaisse-Lagae, F., Ravazzola, M., Malaisse, W. J., Perrelet, A., Renold, A. E.: Islet cell membrane alteration by diabetogenic drugs. Lab. Invest. 34, 451-454 (1976)

8. Watkins, D., Cooperstein, S. J., Lazarow, A.: Effect of sulphydryl reagents on permeability of toadfish islet tissue. Am. J. Physiol. 219, 503-509 (1970)

9. Mc Daniel, M. L., Anderson, S., Fink, J., Roth, C., Lacy, P. E.: Effect of alloxan on permeability and hexose transport in rat pancreatic islets. Endocrinology 97, 68-75 (1975)

10. Henquin, J. C.: D-glucose inhibits potassium efflux from pancreatic islet cells. Nature 271, 271-273 (1978)

11. Sehlin, J., Täljedal, I.-B.: Glucose-induced decrease in $\mathbf{R b}^{+}$ permeability in pancreatic $\beta$-cells. Nature 253, 635-636 (1975)

12. Dean, P.M., Matthews, E. K.: Glucose-induced electrical activity in pancreatic islet cells. J. Physiol. (Lond.) 210, 255-264 (1970)

13. Meissner, H. P., Schmelz, H.: Membrane potential of beta cells in pancreatic islets. Pflügers Arch. 351, 195-206 (1974)

14. Henquin, J. C.: Tetraethylammonium potentiation of insulin release and inhibition of rubidium efflux in pancreatic islets. Biochem. Biophys. Res. Commun. 77, 551-556 (1977)

15. Meissner, H. P., Henquin, J. C.: The potassium permeability of pancreatic B-cells: importance of its changes for insulin release and electrical activity. Diabetes 27 (Suppl. 2), 457 (1978)

16. Henquin, J. C., Meissner, H. P.: Valinomycin inhibition of insulin release and alteration of the electrical properties of pancreatic B-cells. Biochim. Biophys. Acta 543, 455-464 (1978)

17. Tomita, T., Lacy, P. E., Matschinsky, F. M., Mc Daniel, M. L.: Effect of alloxan on insulin secretion in isolated rat islets perifused in vitro. Diabetes 23, 517-524 (1974)

18. Henquin, J. C., Lambert, A. E.: Bicarbonate modulation of glucose-induced biphasic insulin release by rat islets. Am. J. Physiol. 231, 713-721 (1976)

19. Ashcroft, S. J. H., Weerasinghe, L.C.C., Bassett, J. M., Randle, P. J.: The pentose cycle and insulin release in mouse pancreatic islets. Biochem. J. 126, 525-532 (1972)

20. Tomita, T.: Effect of alloxan on arginine- and leucine- induced insulin secretion in isolated islets. FEBS Lett. 72, 79-82 (1976)

21. Rossini, A. A., Arcangeli, M. A., Cahill, G. F.: Studies of alloxan toxicity on the beta cell. Diabetes 24, 516-522 (1975)

22. Tomita, T., Scarpelli, D. G.: Interaction of cyclic AMP and alloxan on insulin secretion in isolated rat islets perifused in vitro. Endocrinology 100, 1327-1333 (1977)
23. Jain, K., Logothetopoulos, J.: Proinsulin biosynthesis by pancreatic islets of the rat and the study of alloxan cytotoxicity in vitro. Biochim. Biophys. Acta 435, 145-151 (1976)

24. Schönborn, J., Westphal, P., Panteń, U.: Insulin release from the isolated perfused rat pancreas induced by L-leucine, 2aminonorbormane-2-carboxylic acid and $\alpha$-ketoisocaproic acid. Horm. Metab. Res. 7, 127-131 (1975)

25. Henquin, J.C.: Possible mechanism of tolbutamide acute stimulation and secondary inhibition of insulin release by perifused rat islets. Diabetologia 13, 401 (1977)

26. Matthews, E. K., Dean, P. M., Sakamoto, Y.: The bioelectrical activity of the islet cell membrane. In: Insulin II. Hasselblatt, A., Bruchhausen, F. V. (Eds.), pp. 157-174. Berlin, Heidelberg, New York: Springer 1975

27. Meissner, H. P.: Electrical characteristies of the beta cells in pancreatic islets. J. Physiol. (Paris) 72, 757-767 (1976)

28. Dean, P. M., Matthews, E. K., Sakamoto, Y.: Pancreatic islet cells: effects of monosaccharides, glycolytic intermediates and metabolic inhibitors on membrane potential and electrical activity. J. Physiol. (Lond.) 246, 459-478 (1975)

29. Gunnarsson, R., Hellerström, C.: Acute effects of alloxan on the metabolism and insulin secretion of the pancreatic $\mathrm{B}$ cell. Horm. Metab. Res. 5, 404-409 (1973)

30. Borg, L. A. H., Eide, S., Andersson, A., Agren, A., Ostenson, C.-G., Hellerström, C.: In vitro effects of alloxan on glucose utilization and ATP content of isolated mouse pancreatic islets. Diabetologia 13, 383-384 (1977)

31. Gunnarsson, R.: Inhibition of insulin biosynthesis by alloxan, streptozotocin and N-nitrosomethylurea. Mol. Pharmacol. 11, 759-765 (1975)

32. Niki, A., Niki, H., Miwa, I., Lin, B. J.: Interaction of alloxan and anomers of D-glucose on glucose-induced insulin secretion and biosynthesis in vitro. Diabetes 25, 574-579 (1976)

33. Hammarström, L., Ullberg, S.: Specific uptake of labelled alloxan in the pancreatic islets. Nature 212, 708-709 (1966)

34. Weaver, D. C., Mc Daniel, M. L., Lacy, P. E.: $\left[2-{ }^{14} \mathrm{C}\right]$-Alloxan uptake by isolated rat islets. Diabetes 26 (Suppl. 1), 380 (1977)

35. Carter, W. J., Younalton, E. S.: Studies on protection against the diabetogenic effect of alloxan by glucose. Proc. Soc. Exp. Biol. Med. 109, 611-612 (1962)

36. Mc Daniel, M., Roth, C., Fink, J., Fyfe, G., Lacy, P. E.: Effects of cytochalasins $B$ and $D$ on alloxan inhibition of insulin release. Biochem. Biophys. Res. Commun. 66, 1089-1096 (1975)

Received: July 28, 1978,

and in revised form: October 17,1978

Dr. J. C. Henquin

Unité de Diabète et Croissance

University of Louvain, UCL 54.74

B-1200 Brussels

Belgium 